\title{
Review
}

\section{Integrative review of the evaluation of health communication campaigns for HIV prevention in Latin American mass media*}

Revisão integrativa sobre avaliação das campanhas de comunicação em saúde para prevenção do HIV nos meios de comunicação da América Latina (resumo: p. 16)

Revisión integradora sobre la evaluación de las campañas de comunicación en salud para la prevención del VIH en medios de comunicación masiva en América Latina (resumen: p. 16)

Jair Vega-Casanova ${ }^{(a)}$

<jvega@uninorte.edu.co>

Alicia Camelo-Guarín ${ }^{(\mathrm{b})}$

<acamelo@uninorte.edu.co>

Ana María del Río-González(c)

<amdelrio@gwmail.gwu.edu> (iD)

Jorge Palacio-Sañudo(d)

<jpalacio@uninorte.edu.co>
This article is a part of the Ph.D. Thesis: Alicia Camelo-Guarín. Influence of edu-entertainment messages (written vs. audiovisual) on the intention to take an HIV test: the moderating role of the need for cognition and the ability to generate mental images. Universidad del Norte, Barranquilla.

continued on page 13

An integrative review of the literature of the last thirty years on evaluations of HIV prevention strategies implemented in the mass media in Latin America was conducted. A total of 246 documents were identified, of which 12 met the selection criteria and 15 campaign evaluations were identified. The results indicate that the most commonly used message was to promote the use of condoms. Most evaluations focused on remembering the message of campaigns and media exposure. Only three yield results on knowledge assessments and two on attitudes to condom use; nine reported behavioral changes. In conclusion, there are few articles with evaluation results. The assessment of behaviors is increasingly taken into account. Pre-experimental evaluation designs are used.

Keywords: Campaigns. HIV/Aids prevention. Social marketing. Health communication. Latin America.

Vega-Casanova J, Camelo-Guarín A, del Río-González AM, Palacio-Sañudo J. Integrative review of the evaluation of health communication campaigns for HIV prevention in Latin American mass media. Interface (Botucatu). 2020; 24 e200154 https://doi.org/10.1590/interface.200154 


\section{Introduction}

Despite the efficacy demonstrated by antiretroviral treatments, the Human Immunodeficiency Virus (HIV) and Acquired Immune Deficiency Syndrome (AIDS) pose a serious global problem. It is estimated that in 201736.9 million people were living with HIV worldwide, of which 1.8 million live in Latin America ${ }^{1}$. Mass media campaigns have become a priority for preventive efforts in the fight against HIV and research has been instrumental in making progress against the spread of the epidemic ${ }^{2}$. However, it is recognized that HIV advertising campaigns in general, and especially those broadcasts on television, have shown very little effect in achieving changes in risk behaviors ${ }^{3}$. At this moment everything seems to indicate that the epidemic spreads much faster than the preventive actions that seek to stop it. Sharing successes, failures, and lessons learned can contribute to a reverse of this trend ${ }^{4}$.

According to Breton ${ }^{5}$, in the absence of a preventive vaccine for HIV, campaigns advocating safe-sex to prevent the epidemic have been positively assessed. In 1987, HIV prevention campaigns began to be broadcast ${ }^{6}$, becoming in many countries one of the most important resources for transmitting preventive information ${ }^{7}$.

There is important literature on prevention-oriented health campaigns that report evaluations of successful campaigns and their most common shortcomings. Since a long time ago, Rogers \& Storey ${ }^{8}$, in reviewing campaign history, consider the 1940 s and 1950 s to be an era of minimal effects, when many large-scale campaign efforts failed. The 1960s and 1970s marked the beginning of campaigns that were successful and, principles of effective campaign design were formulated, including: 1) using a formative evaluation for their design, 2) setting reasonable goals, 3) using audience fragmentation, and 4) considering interpersonal communication networks. These principles coincide with those that Noar ${ }^{9}$ propose recently and considers necessary to guarantee the success of a health campaign. Finally, the 1980s and 1990s are defined as an era of moderate effects.

As for the effect of the campaigns, there has been an important debate. Since the late ' 80 s, authors such as Flay \& Cook $^{10}$ suggested that social marketing rarely changes behavior directly, but instead creates awareness, modifies or influences perceptions, and provides motivation to change attitudes about an issue ${ }^{11}$. Based on the results of a 2004 metaanalysis, on the contrary, they affirm that campaigns promoting the adoption of healthy behaviors are associated with small but significant changes in behavior. In the same vein, Noar' argues that the literature is beginning to accumulate evidence that these well-targeted and executed campaigns can have small to moderate effects not only on health knowledge, beliefs and attitudes, but also on behaviors. Coffman ${ }^{12}$ states that no progress has been made on innovation in campaign evaluation as funders are more focused on results.

Some reviews on evaluations of HIV prevention campaigns conducted in the first decade of the 21st century considered that HIV/Aids campaigns can have an impact on the knowledge, attitudes, and behaviors related to HIV ${ }^{13-16}$. These reviews questioned the effectiveness of the interventions due to the fact that they continue to use weak designs for evaluating results (ie, pre-experimental). 
The most recent reviews continuo to show that there is a growing body of evidence on the effectiveness of social marketing and media interventions to increase condom use, knowledge related to HIV and the adherence to HIV testing. Unlike the previous ones, these studies explored the patterns in the type of study, internal validity and the effectiveness of the interventions ${ }^{17-20}$. Likewise, they analyzed HIV/Aids prevention programs through reference criteria, in order to identify gaps between the design of the programs and their effectiveness ${ }^{21}$.

In Latin America were observed changing trends. In the 1980s the reign of silence prevailed or messages seemed only whispered. In the 1990s, the voices began to become louder, beginning with the use of social marketing. At the end of the 2000's, strategies became diversified and a dialogue sprang up among all actors, including the most vulnerable groups, health personnel, opinion leaders, and the general population ${ }^{22}$.

Studies aimed at evaluating the impact of campaigns are now considered essential ${ }^{23}$. In the initial evaluations, informed condom use, reduction in the number of sexual partners, or the risk of sexually transmitted diseases were highlighted as central issues ${ }^{24}$. In other evaluations, the psychological dimensions of affection, cognition and behavior were observed for better persuasiveness of the campaigns, as well as the mediating effect of the relevant sociodemographic and behavioral characteristics to adopt healthy behaviors and avoid risky behaviors ${ }^{23,25,26}$.

However, despite major efforts and economic investments over the past thirty years to curb the spread of HIV, campaigns often go unevaluated ${ }^{27}$, or lack rigorous evaluation ${ }^{14}$.

Based on the above considerations, it is necessary to conduct a literature review on the evaluation of HIV prevention campaigns through mass media that have been implemented in Latin America, in order to identify: if campaigns are being evaluated ${ }^{14,27}$ and the methodological quality of the evaluations ${ }^{17-21}$, the approaches and variables that are being used ${ }^{13-16,24}$, and the target audiences ${ }^{22,23,25,26}$, in a way that allows us to make a series of recommendations about the implementation and the evaluation of this type of campaigns in the region.

\section{Materials and methods}

We followed the recommendations of Souza, Silva, \& Carvalho ${ }^{28}$ for conducting integrative review. We searched for articles indexed in the following health and social science communication databases: Scopus, Web of Science, Science Direct, ProQuest, Google Scholar, Dialnet Plus, Redalyc Clacso and Scielo. We conducted this search in both Spanish and English, using the following search terms: "HIV/Aids and health campaigns", "Evaluation HIV/Aids campaigns", "Evaluation HIV/Aids prevention campaigns in Latin America", "Analysis of HIV/Aids prevention campaigns". Because no Portuguese keywords were used, articles with evaluations of campaigns published in this language, and probably implemented in Brazil, are not included.

This initial search yielded 246 publications that included: articles, guides or government documents, book chapters, conference, and postgraduate theses related to HIV prevention interventions in mass media implemented in Latin America. Bibliographies of these studies were also reviewed to identify relevant assessments omitted from the results of electronic 
searches. This review provided four additional studies. We reviewed this initial set of documents to exclude those that did not report empirical findings of campaign evaluations; 187 documents were excluded at this stage.

To be included in the present review, documents had to meet the following criteria: a) have been published between 1990 and 2018, since the appearance of the first published document on campaign evaluation; b) present empirical findings of the evaluation of an HIV prevention campaign in mass media in Latin America or reports from the agencies that carried out the evaluations; and c) present findings regarding the impact of the intervention, including variables such as HIV knowledge, attitudes, and behaviors. According to these criteria, 51 documents were excluded.

Initially, only peer-reviewed studies were going to be included, but due to the lack of found documents, it was chosen to include institutional documents and master's degree thesis. This limitation has also been presented in studies conducted in other contexts ${ }^{14,21}$.

The final set consisted of 12 documents, including: nine peer-reviewed articles, two institutional documents, and one Master's dissertation.

Although, at present, the reviews focus on the characteristics of the evaluations and their internal validity to establish effects and results ${ }^{17-20}$, the documents found for this review do not allow for similar ways to analyze the evaluations, since there is no homogeneity in the results, designs, methods, and samples.

Subsequently, the rules for the coding of documents were defined. Each document was coded by three of the authors and in case of differences, these were discussed with the set of authors. The results of this coding were organized in two tables: one with the characteristics of the campaigns evaluated (Table 1 ) and another with the results of the evaluation of the campaigns (Table 2), which are presented below. In order to classify the results in the evaluation of the campaigns, we considered the most common variables in this type of intervention, which emerged in the second filtering of the documents. The first two variables refer to the process of reception of the campaigns (recall and attitude towards the campaigns) and the others to their results:

- Recall: is a measure of expresses the weight of media and the ability of creative execution to attract attention and position either a campaign in the memory of the target audience ${ }^{29}$.

- Attitude towards the campaigns: degree of favorability or agreement in relation to the messages, clarity or potential results of campaigns.

- Knowledge: refers to how much the target audience knows about different aspects of a campaign. Knowledge is a significant reference for action or response to a stimulus - Theory of Reasoned Action- ${ }^{30}$.

- Attitudes: Coffman ${ }^{12}$ states that attitudes are a person's affection for or against an object.

- Behaviors: for Ajzen \& Fishbein ${ }^{30}$, is the end result of a set of predictors in which cognitive or emotional responses are included that are expected to result in the elimination or reduction of obstacles to change. 
It would have been interesting to include variables such as the use of theory to understand pathways to change, time of interventions, etc. But the information collected did not allow conclusions to be drawn on those aspects.

\section{Results}

A total of 12 documents were identified that presented 15 evaluations of HIV prevention campaigns in the mass media in several Latin American countries. About five evaluate several campaigns ${ }^{31-35}$, three documents do not assess a particular campaign but rather the recall of HIV campaigns in a specific population ${ }^{36-38}$ and four evaluate a specific prevention campaign ${ }^{39-42}$.

\section{Description of the campaigns}

Table 1. Characteristics of the campaigns evaluated

\begin{tabular}{|c|c|c|c|c|c|c|c|}
\hline \# & Author(s) & Country & Campaign Name & Campaign year & Medium(s) & $\begin{array}{l}\text { Target audience of } \\
\text { the evaluation }\end{array}$ & Message \\
\hline 1 & $\begin{array}{l}\text { Vernon R, Ojeda } \\
\text { G, Murad R. }{ }^{31}\end{array}$ & $\mathrm{COL}$ & $\begin{array}{l}\text { PROFAMILIA campaign, slogan: } \\
\text { "Los hombres preparados no } \\
\text { mueren de SIDA" ("Prepared } \\
\text { men don't die of AIDS") and "Si } \\
\text { tienes relaciones sexuales en las } \\
\text { próximas } 24 \text { horas, piensa en } \\
\text { el SIDA y piensa en un condón } \\
\text { seguro. Tahití, un condón } \\
\text { seguro" ("If you have sex in the } \\
\text { next } 24 \text { hours, think about AIDS } \\
\text { and think about a safe condom. } \\
\text { Tahiti, a safe condom”). }\end{array}$ & 1988 & Radio & General population. & $\begin{array}{l}\text { Condom use in AIDS } \\
\text { prevention }\end{array}$ \\
\hline 2 & $\begin{array}{l}\text { Rico B, } \\
\text { Bronfman M, } \\
\text { Del Rio C. }{ }^{32}\end{array}$ & MEX & $\begin{array}{l}\text { "Disfruta con responsabilidad" } \\
\text { ("Enjoy responsibly"), “¿No } \\
\text { cree que debería informarse?" } \\
\text { ("Don’t you think you should } \\
\text { get informed?"), "... y tú qué } \\
\text { estás haciendo?" ("... and what } \\
\text { are you doing?"), "El SIDA no } \\
\text { es cuestión de..." ("AIDS is not } \\
\text { a matter of..."), "La mujer y el } \\
\text { SIDA" ("Women and AIDS”), } \\
\text { "Quítate la venda de los ojos" } \\
\text { ("Take off your blindfold"). }\end{array}$ & 1987 a 1994 & $\begin{array}{l}\text { TV, radio } \\
\text { and poster } \\
\text { spots }\end{array}$ & $\begin{array}{l}\text { General population, } \\
\text { at-risk groups, women } \\
\text { and adolescents. }\end{array}$ & $\begin{array}{l}\text { HIV/Aids Prevention, } \\
\text { Openness to HIV and } \\
\text { AIDS Communication }\end{array}$ \\
\hline 3 & Burgos M. ${ }^{33}$ & ARG & $\begin{array}{l}\text { "AIDS Kills", "drugs are always } \\
\text { sex with AIDS", "AIDS: don't let } \\
\text { yourself fall in a the trap". }\end{array}$ & No information & $\begin{array}{l}\text { Posters, } \\
\text { flyers and } \\
\text { TV spots }\end{array}$ & General population. & HIV risk behaviors \\
\hline 4 & Roso A. ${ }^{34}$ & BRAZ & $\begin{array}{l}\text { "Hebe", "Eu confio" ("I trust”), } \\
\text { "Eliakim Araújo", "Leila Cordeiro", } \\
\text { "Galinha", "Carnaval" ("Carnival") } \\
\text { and "Pega - Não Pega" }\end{array}$ & No information & TV Spots & $\begin{array}{l}\text { Low-class women, } \\
\text { between } 18 \text { and } 51 \\
\text { years old. }\end{array}$ & Condom use \\
\hline 5 & $\begin{array}{l}\text { Vera-Gamboa } \\
\text { L, Cen-Chablé } \\
\text { M, Góngora- } \\
\text { Bianchi RA. }{ }^{37}\end{array}$ & MEX & No information & No information & $\begin{array}{l}\text { No } \\
\text { information }\end{array}$ & Gay men. & $\begin{array}{l}\text { Knowledge of HIV/Aids } \\
\text { and risky sexual practices }\end{array}$ \\
\hline 6 & $\begin{array}{l}\text { Vera-Gamboa } \\
\text { L, Cerón- } \\
\text { Bracamonte } \\
\text { B, Góngora- } \\
\text { Bianchi RA. }{ }^{36}\end{array}$ & MEX & No information & No information & $\begin{array}{l}\text { No } \\
\text { information }\end{array}$ & $\begin{array}{l}\text { Men who have sex } \\
\text { with men. }\end{array}$ & $\begin{array}{l}\text { Knowledge, attitudes, } \\
\text { sexual practices, } \\
\text { perception of HIV/Aids risk }\end{array}$ \\
\hline
\end{tabular}




\begin{tabular}{|c|c|c|c|c|c|c|c|}
\hline$\#$ & Author(s) & Country & Campaign Name & Campaign year & Medium(s) & $\begin{array}{l}\text { Target audience of } \\
\text { the evaluation }\end{array}$ & Message \\
\hline 7 & Porto MP.40 & BRAZ & $\begin{array}{l}\text { "Campanha de Carnaval" } \\
\text { ("Carnival Campaign"). }\end{array}$ & 2003 & $\begin{array}{l}\text { Poster, radio } \\
\text { and TV } \\
\text { spots }\end{array}$ & $\begin{array}{l}\text { Adolescent women } \\
\text { between the ages of } \\
13 \text { and } 19 .\end{array}$ & $\begin{array}{l}\text { Demand condom use } \\
\text { from sexual partners }\end{array}$ \\
\hline 8 & $\begin{array}{l}\text { Flores F, De Alba } \\
M .^{38}\end{array}$ & MEX & Not applicable & No information & $\begin{array}{l}\text { No } \\
\text { information }\end{array}$ & $\begin{array}{l}\text { University students } \\
\text { between the ages of } \\
17 \text { and } 25 \text {. }\end{array}$ & $\begin{array}{l}\text { Social Representation } \\
\text { of AIDS }\end{array}$ \\
\hline \multirow{4}{*}{9} & \multirow{4}{*}{$\begin{array}{l}\text { Gobierno de } \\
\text { Chile, Ministerio } \\
\text { de Salud } \\
\text { (Government of } \\
\text { Chile, Ministry } \\
\text { of Health) } \\
\text { (undated) }\end{array}$} & \multirow{4}{*}{ CHIL } & $\begin{array}{l}\text { "Lo único mortal del VIH es no } \\
\text { saber que lo tienes. Hazte el } \\
\text { examen a tiempo" ("The only } \\
\text { deadly thing about HIV is not } \\
\text { knowing you have it. Take the } \\
\text { test on time"). }\end{array}$ & 2003 & $\begin{array}{l}\text { Billboards, } \\
\text { radio, TV } \\
\text { spots }\end{array}$ & $\begin{array}{l}\text { General, older than } 15 \\
\text { years sexually active. }\end{array}$ & $\begin{array}{l}\text { Get tested for HIV. } \\
\text { Effective self-care when } \\
\text { exposed to HIV risk }\end{array}$ \\
\hline & & & $\begin{array}{l}\text { "Frente al SIDA, yo tengo una } \\
\text { postura" ("In the face of AIDS, I } \\
\text { have a stance"). }\end{array}$ & 2005 & $\begin{array}{l}\text { Billboards, } \\
\text { radio, TV } \\
\text { spots }\end{array}$ & $\begin{array}{l}\text { General, older than } 15 \\
\text { years sexually active. }\end{array}$ & $\begin{array}{l}\text { Stimulate in the } \\
\text { population the } \\
\text { conversation about one's } \\
\text { own sexual experience }\end{array}$ \\
\hline & & & $\begin{array}{l}\text { "Mi vida la cuido toda la vida, } \\
\text { siempre condón" ("My life I } \\
\text { take care of all my life, always } \\
\text { condom"). }\end{array}$ & 2006 & $\begin{array}{l}\text { Billboards, } \\
\text { TV spots }\end{array}$ & $\begin{array}{l}\text { Women and men } \\
\text { between the ages of } \\
15 \text { and } 30 .\end{array}$ & $\begin{array}{l}\text { Consistent use of } \\
\text { condoms, as a preventive } \\
\text { measure, at all times when } \\
\text { there is a risk of sexual } \\
\text { transmission of HIV }\end{array}$ \\
\hline & & & $\begin{array}{l}\text { "Yo decido, me cuido siempre" } \\
\text { ("I decide, I always take care of } \\
\text { myself"). }\end{array}$ & 2007 & $\begin{array}{l}\text { Radio and } \\
\text { TV spots }\end{array}$ & $\begin{array}{l}\text { Adolescents and } \\
\text { young people } \\
\text { between the ages of } \\
15 \text { and } 30 \text {. }\end{array}$ & $\begin{array}{l}\text { Increase consistent } \\
\text { condom use as a } \\
\text { preventive measure }\end{array}$ \\
\hline 10 & $\begin{array}{l}\text { Ahumada M, } \\
\text { Ruiz M, Parra } \\
\text { V. }^{41}\end{array}$ & CHIL & $\begin{array}{l}\text { "Hazte el examen" ("Get } \\
\text { tested") }\end{array}$ & 2011 & $\begin{array}{l}\text { TV spots, } \\
\text { radio, written } \\
\text { press and } \\
\text { through a } \\
\text { website. }\end{array}$ & $\begin{array}{l}\text { At-risk populations } \\
\text { (e.g., men who } \\
\text { have sex with men, } \\
\text { transgender people } \\
\text { and sex workers). }\end{array}$ & Conducting an HIV test \\
\hline 11 & Reynaga C. ${ }^{42}$ & PER & $\begin{array}{l}\text { "Cabeza Caliente" } \\
\text { "Hot Head." }\end{array}$ & 2008 & $\begin{array}{l}\text { TV spots } \\
\text { and posters }\end{array}$ & $\begin{array}{l}\text { Students in } 5 \text { th } \\
\text { year of secondary } \\
\text { school, from } 15 \text { to } \\
19 \text { years old. }\end{array}$ & Condom use \\
\hline 12 & $\begin{array}{l}\text { Nielsen R, } \\
\text { Luengo M, Mello } \\
\text { M, Paz J, Pantin } \\
\text { C, Erkkola T. }{ }^{39}\end{array}$ & BRAZ & $\begin{array}{l}\text { "Zero Discrimination } \\
\text { campaign" }\end{array}$ & 2014 & $\begin{array}{l}\text { Social } \\
\text { Networks }\end{array}$ & General population & $\begin{array}{l}\text { Non-discrimination } \\
\text { towards people living with } \\
\text { HIV or AIDS }\end{array}$ \\
\hline
\end{tabular}

Table 1 presents the description of the 15 related campaigns in the 12 documents reviewed. The first evaluation of a campaign was found in Colombia in $1990^{31}$ and the most recent in Brazil in $2017^{39}$.

About eight of the campaings evaluated targeted a general audience ${ }^{31,33,35,39}$, six targeted adolescents and young adults ${ }^{32,34,38,40}$, three were designed for women ${ }^{32,34,40}$, and two were designed for at-risk groups (e.g., men who have sex with men, transgender people and sex workers) $)^{32,41}$.

The most common message in the campaigns was the promotion of condom use $(n=6)^{31,34,35,40,42}$. Abot two focused on stimulating discussion of HIV/Aids ${ }^{33,35}$, two promoted HIV testing ${ }^{32,35}$, two reported on HIV behaviors, practices and risk perception ${ }^{35,41}$, one focused on non-discrimination towards people living with HIV or AIDS ${ }^{39}$, and one emphasized the importance of the media in the social representation of $\mathrm{AIDS}^{38}$. 


\section{Description of the evaluations}

Table 2. Results evaluated in the campaigns

\begin{tabular}{|c|c|c|c|c|}
\hline$\#$ & Evaluation method & Sample & Type of evaluation & Results \\
\hline 1 & Baseline and final surveys. & $\begin{array}{l}\text { General population ( } \mathrm{N}=944 \\
\text { baseline, and } 1440 \text { final sample). }\end{array}$ & Recall. & $\begin{array}{l}\text {-HIV knowledge/belief. } \\
\text {-Attitudes towards condom use. } \\
\text {-Behaviors (Use and purchase of condoms). }\end{array}$ \\
\hline 2 & In-depth interviews. & $\begin{array}{l}\text { General population (N not } \\
\text { specified), leaders of NGO's and } \\
\text { opinion leaders interested in the } \\
\text { problem of AIDS }(\mathrm{N}=7) \text {. }\end{array}$ & No information & $\begin{array}{l}\text {-Attitudes towards messages/campaigns. } \\
\text {-Behavior/attitudes towards the demand for } \\
\text { counseling via telephone calls. } \\
\text {-Behaviors (Discussion in the social environment } \\
\text { about prevention). }\end{array}$ \\
\hline 3 & Survey and interviews. & General population $(N=5,000)$. & Recall. & $\begin{array}{l}\text {-Behaviors (Reduction in the number of sexual } \\
\text { partners). } \\
\text {-Behavior/attitudes towards the demand for } \\
\text { counseling via telephone calls. }\end{array}$ \\
\hline 4 & $\begin{array}{l}\text { Focus groups after observing } \\
7 \text { campaigns and individual } \\
\text { interviews. }\end{array}$ & $\begin{array}{l}\text { Two groups of women: those } \\
\text { who participate in groups fighting } \\
\text { HIV/Aids and those who do not } \\
\text { participate in these activities. }\end{array}$ & Means of exhibition. & Attitudes towards messages/campaigns. \\
\hline 5 & $\begin{array}{l}\text { Questionnaire and semi- } \\
\text { structured interview. }\end{array}$ & $\operatorname{MSM}(N=14)$ & Recall. & No information \\
\hline 6 & $\begin{array}{l}\text { Questionnaire and semi- } \\
\text { structured interview. }\end{array}$ & $\operatorname{MSM}(N=50)$ & Recall. & No information \\
\hline 7 & $\begin{array}{l}\text { Survey with open and closed } \\
\text { questions. }\end{array}$ & $\begin{array}{l}\text { Adolescent women aged 13-19 } \\
(\mathrm{N}=1,006) .\end{array}$ & $\begin{array}{l}\text {-Means of exposure. } \\
\text {-Recall. }\end{array}$ & $\begin{array}{l}\text {-Attitudes towards condom use. } \\
\text {-Behavior/attitudes towards the demand for } \\
\text { counseling via telephone calls. }\end{array}$ \\
\hline 8 & $\begin{array}{l}\text { Questionnaire with open and } \\
\text { closed questions. }\end{array}$ & $\begin{array}{l}\text { University students } \\
(\mathrm{N}=400)\end{array}$ & Means of exhibition. & Attitudes towards messages/campaigns. \\
\hline \multirow{4}{*}{9} & Telephone interviews. & $\begin{array}{l}\text { Men and women aged } 15-60 \text {, } \\
\text { sexually active } \\
(\mathrm{N}=2,860)\end{array}$ & Recall. & $\begin{array}{l}\text {-Attitudes towards messages/campaign. } \\
\text {-Behavior/attitudes towards the demand for } \\
\text { counseling via telephone calls. } \\
\text {-HIV knowledge/belief. } \\
\text {-Behavior. }\end{array}$ \\
\hline & Telephone survey. & $\begin{array}{l}\text { General population over } 15 \text { years } \\
\text { of age sexually active }(N=1,004)\end{array}$ & $\begin{array}{l}\text {-Means of exposure. } \\
\text {-Recall }\end{array}$ & $\begin{array}{l}\text {-Attitudes towards messages/campaigns. } \\
\text {-Behavior/attitudes towards the demand for } \\
\text { counseling via telephone calls. }\end{array}$ \\
\hline & Telephone Interviews. & $\begin{array}{l}\text { Adolescents and young people } \\
\text { aged } 15 \text { to } 30(N=1,616) \text {. }\end{array}$ & -Recall & $\begin{array}{l}\text {-Attitudes towards messages/campaign. } \\
\text {-HIV knowledge/belief. } \\
\text {-Behavior/attitudes towards the demand for } \\
\text { counseling via telephone calls. }\end{array}$ \\
\hline & Telephone interviews. & $\begin{array}{l}\text { Adolescents and young people } \\
\text { aged } 15 \text { to } 30(N=1,680) \text {. }\end{array}$ & $\begin{array}{l}\text {-Means of exposure. } \\
\text {-Recall. }\end{array}$ & $\begin{array}{l}\text {-Attitudes towards messages/campaign. } \\
\text {-Behavior/attitudes towards the demand for } \\
\text { counseling via telephone calls. }\end{array}$ \\
\hline 10 & $\begin{array}{l}\text { Press analysis, general } \\
\text { population survey, semi- } \\
\text { structured interview with people } \\
\text { linked to health and analysis } \\
\text { of content and discourse of } \\
\text { the opinions of various social } \\
\text { sectors. }\end{array}$ & $\begin{array}{l}\text { General population }(N=137) \text { and } \\
\text { key informants }(N=14) \text {. }\end{array}$ & No information & $\begin{array}{l}\text {-Attitudes towards messages/campaign. } \\
\text {-Behaviors (HIV testing). } \\
\text {-Behavior/attitudes towards the demand for } \\
\text { counseling via telephone calls. }\end{array}$ \\
\hline 11 & Survey. & $\begin{array}{l}\text { Secondary school students aged } \\
15-19(N=440)\end{array}$ & $\begin{array}{l}\text {-Means of exposure. } \\
\text {-Recall. }\end{array}$ & No information \\
\hline 12 & Content analysis. & $\begin{array}{l}\text { Posted tweets on HIV and AIDS } \\
\text { and discrimination, published } \\
\text { between January } 2014 \text { and March } \\
2015(\mathrm{~N}=7546) \text {. }\end{array}$ & No information & $\begin{array}{l}\text {-Behavior (increased demand for HIV testing). } \\
\text {-Behavior/attitudes towards the demand for } \\
\text { counseling via telephone calls. }\end{array}$ \\
\hline
\end{tabular}

Table 2 presents the methodological characteristics and results of the evaluations carried out on the campaigns. 
The results will be presented according to the main variable evaluated, which may be: means of exposure, recall and attitude towards the campaigns, knowledge, attitude and behavior.

\section{Means of exposure}

A total of six documents agreed that television is the most effective medium: between $80 \%$ and $96 \%$ of those who remembered a campaign saw it through this medium. Radio and posters are secondary media where participants remember seeing or hearing campaign advertisements $\mathrm{s}^{34,35,38,40,42}$.

\section{Recall}

Most of the documents reviewed $(n=9)$ include results related to the evaluation of campaign recall. There is a high recall of these campaigns: between $67-100 \%$ of the participants in the different studies reported having seen, heard, or read a message about HIV or AIDS in the media. There is less recall when evaluating campaigns aimed at specific segments of the population ${ }^{36,37,42}$.

Recall is also lower when evaluating campaign-specific messages, themes or texts ${ }^{31,33,40}$.

\section{Attitude towards the campaign}

The results in eight studies show that there is no consensus on attitudes towards messages and campaigns. In some cases, the campaigns have been criticized for using crude and direct language that generates rejection and does not help to increase risk perception or safer practices ${ }^{41}$. Other authors argue that progress in HIV prevention cannot be achieved using the same traditional approaches and that innovative campaigns are needed, even if they ruffle some feathers among the general public ${ }^{32}$.

Differences were also observed in attitudes towards campaigns, even when they are aimed at the same population group. For example, in a study with Brazilian women with similar characteristics in terms of age and stratum, it was evident that the message is received in a different way. The participants who were part of organizations that fight against HIV/Aids do not agree or identify with most of the messages, while those of the other group do (women who participate in pre-existing groups that are not directed to the prevention of HIV/Aids) ${ }^{34}$.

\section{Knowledge}

Only three of the 15 evaluations show evidence of results in terms of knowledge about HIV prevention. The research of Vernon et al. ${ }^{31}$ in Colombia shows increases between baselines from 9 to $30 \%$ in the knowledge of condom use as a behavior to prevent HIV. Similarly, in Chile's campaigns, the majority of people (82\%) believe that condoms are a good way to prevent $\mathrm{HIV}$, and $97 \%$ recognize that AIDS is a disease that can affect anyone ${ }^{35}$. 


\section{Attitudes}

Only in two of the documents are attitudinal aspects evaluated and specifically related to condom use. Vernon et al. ${ }^{31}$ found an increase in the attitude towards the condom score from 4.76 in the baseline to 6.75 in the final line $(p<01)$. Likewise, the exposure to the "Campaña del Carnaval" among adolescent women in Brazil ${ }^{40}$ was significantly associated with more positive attitudes towards the purchase of condoms.

\section{Behaviors}

Results are reported in four behaviors: discussion on issues related to HIV and sexual and reproductive health in general, use of telephone counseling for HIV prevention, HIV testing, and condom use.

Exposure to the campaigns generally stimulated discussions in the social environment about prevention, and most respondents reported that the campaign made them rethink their position on HIV/Aids, generating reflection and a more open discussion about prevention with their partner, friends, teachers, doctors and family ${ }^{32,33,35,40}$.

Regarding HIV testing, in research conducted in Chile, only 3.6\% of 137 respondents said they had taken the test after seeing the campaign ${ }^{41}$.

In the evaluation of behavioral aspects, 6 studies were found where there is an increase in condom use ${ }^{31,40}$, a greater demand for testing ${ }^{32,39,41}$, and a reduction in the number of sexual partners ${ }^{33}$. Although most of the campaigns included messages focused on promoting condom use, only one of the documents assessed behavioral aspects of condom use ${ }^{31}$.

\section{Discussion}

\section{Low number of prevention campaigns and limited evaluation of the campaigns}

The results show that there are few publications of evaluations carried out on HIV prevention campaigns in the mass media in Latin America. Chile ranks first in the number of published evaluations, where - between 2014 and 2017 - there is almost one campaign evaluation per year, and significantly higher in comparison with other countries in the region. The absence of publications can be explained by the fact that: 1) countries do not carry out the respective evaluations of the prevention campaigns that they implement either due to budgetary limitations or due to the lack of an evaluation culture, 2) there are few published and easily accessible evaluations, 3) in recent years HIV prevention has not necessarily prioritized these type of campaigns.

In the first case, it is clear that despite the importance and usefulness that literature confers on measuring the results and incidence of HIV prevention campaigns $s^{5,23}$, this awareness has barely been assumed by governments and institutions working on this issue in the region. Likewise, there are not always sufficient resources to cover the costs of evaluations when working with limited prevention budgets. 
In the second case, many times the same institutions or entities contracted by sponsors of the programs do the same, more for administrative than academic purposes, which, added to a disarticulation of the academy with these processes, does not allow its scientific validation. The existence of evaluations by the institutions that implement the campaigns in this region is valid. Although not studied by the academy, these initiatives demonstrate that the significance of evaluating the prevention campaigns is not being overlooked. Therefore, in the absence of academic evidence, the inclusion and analysis of these technical management documents becomes relevant when making integrative reviews that allow an approach to these processes.

In the third case, it is observed that in recent years there has been an awareness that the epidemic is concentrated in at-risk populations, and usually prevention messages aimed at these populations use other types of strategies through channels other than the mass media. However, limiting the number of published assessments is a global problem ${ }^{13,21}$.

\section{Moving from general audiences to targeted audiences}

Most of the strategies evaluated in this review are designed for the general population and not for specific groups at risk. In fact, campaigns that attempt to develop messages based on the needs of these populations are criticized because they are not within the moral and prevention standards that have been traditionally handled in Latin countries ${ }^{36}$.

Only the most recent campaigns are beginning to take into account the issue of high risk in targeted populations, as in the case of the "Hazte el examen" campaign in Chile in $2011^{41}$. This result coincides with the review carried out by Noar, et al. ${ }^{15}$ on HIV/Aids mass communication campaigns, considering that the campaigns reviewed between 1998 and 2007 have increasingly employed the strategy of using defined and specific audiences through audience segmentation procedures.

\section{From moral speeches to speeches on rights}

The campaigns analyzed clearly were slow at first in succeeding to transmit their intended messages, going from preventive behavior messages in the first campaigns of the $80 \mathrm{~s}$ and $90 \mathrm{~s}^{31-34}$, to content with a human rights perspective in more recent years ${ }^{35,39-42}$. In fact, Ahumada et al. ${ }^{41}$ consider that all the prevention campaigns carried out in Chile prior to the year 2010 maintained strong prevention content, in some cases moralistic, understood as the modification of personal behaviors that incorporated abstinence from penetrative sexual activity, keeping monogamous and faithful couples, as well as the consistent and correct use of condoms.

Since the mid-1990s, there have been major criticisms in this regard. Burgos ${ }^{33}$ considered that prevention was possible, as long as both the pleasure and the social forms acquired were respected. It recognized, however, that most AIDS campaigns fell back on "moralizing" messages aimed at populations with homogeneous customs. 
(e)

\section{Recall and attitudes towards the messages: there is no identification and representation in the contents}

Audience recall was high on most assessments ${ }^{35,37,42}$. However, in some cases respondents reported low recall of the campaign and specific themes or texts thi,33,35-37,40,42. $^{\text {. }}$ In this case, it is noteworthy that the campaigns aimed at specific audiences or in which specific audiences were evaluated are those with the least recall. It would be necessary to ask about the form of delivery of the messages or the individualization with respect to its punctual necessities.

A little more than half of the documents show evidence of results in terms of attitudes towards the messages and the campaigns carried out ${ }^{32,34,35,38,41}$. On the one hand, campaigns have been criticized for using uncensored language, which generates rejection ${ }^{41}$, and on the other, it is considered necessary to use questioning messages to generate change ${ }^{32}$.

\section{Exposure to the media. TV is the most effective medium}

One of the results most reported by the evaluations conducted in Latin America is the coverage of the campaigns implemented.

Several analyzed evaluations conclude the importance of television as one of the priority sources of transmission of information related to HIV/Aids ${ }^{40,42}$, which is corroborated by Vidanapathirana et al. ${ }^{13}$, who concluded that mass media interventions for the promotion of HIV testing showed an immediate and global effect, but no long-term effects were observed.

\section{From evaluating knowledge and attitudes to evaluating behaviors}

While most of the publications reviewed have focused on assessing campaign recall and messages, there is also a latent interest in assessing the impact of campaigns on knowledge and behaviors related to HIV prevention. Despite the fact that only 3 of the 15 evaluations reviewed show evidence of results in terms of knowledge about HIV ${ }^{31,35}$, in general, it is observed that knowledge of condom use as a means of preventing HIV increased.

Nonetheless, two articles describe the evaluation of attitude towards condom use, with positive results in both cases $^{31,40}$.

With regard to behavioral assessments, campaigns are associated with an increase in condom use ${ }^{31,35}$ and HIV testing ${ }^{39,41}$. They also encourage the use of telephone counseling services for HIV prevention ${ }^{32}$ and to talk to those in their social circle about HIV prevention and about sexual and reproductive health issues, in genera ${ }^{35,40}$. The fact that the majority of these campaigns are directed to the general public and not specific populations such as risk groups -men who have sex with men, expectant mothers, drug addicts, etc.-, could explain why they do not address preventive messages from other forms of infection such as the exchange of syringes, among others. 


\section{Methodological limitations of evaluations}

Regarding the evaluation methods of the campaigns, it can be observed that very basic methods were used and only one evaluation carried out pre- and post-evaluation ${ }^{31}$. In addition, only half of the evaluations used large sample sizes, and most used general population samples. This picture is in line with UNAIDS ${ }^{2}$ assertion that, in the first decade of the $21^{\text {st }}$ century, socio-behavioral HIV prevention programs lacked rigorous evaluation - on an appropriate scale - for widespread implementation ${ }^{15}$.

\section{Conclusions}

This review contributes to an understanding of the status of the evaluation of mass media campaigns focusing on HIV prevention in Latin America. First, there is a shift from general-public campaigns to a focus on specific audiences, although there is still a major challenge in addressing the information needs of groups considered to be at risk. Second, there has been a slow shift away from moralist messages, and human rights discourses have started to emerge as guiding frameworks in the campaigning of HIV prevention. Third, in terms of the results of the campaigns evaluated, researchers have focused on campaign recall, messages and media exposure. Although knowledge, attitudes and behaviors have been included since the first evaluations in the 1990s, the emphasis has been placed on the evaluation of knowledge and attitudes. However, it is clear that behaviors are increasingly assessed.

In terms of limitations, it is observed that very few articles published report results on HIV prevention campaigns in mass media in Latin America. This limited the analysis by the different types of documents analyzed, which is a major challenge, both for the executing institutions and for the academy. It is essential to generate alliances that allow for the design of studies with more sophisticated methodologies and with external evaluations, whose reports can be subjected to peer review that can be published. In this way, there would be references for greater rigor and strength, from the planning itself to the evaluation of the campaigns, based on the evidence.

For future research in the field, it is advisable to carry out a review that includes not only evaluation documents of mass media campaigns, but also interventions based on other communication strategies, other than social marketing, in order to differentiate between them. On the other hand, we also recommend that is necessary to promote alliances with leadership from the academy, seeking the access to support resources from the science and technology institutions, which allow the development of the external evaluations of this type of campaigns implemented by the government and non-governmental institutions, with the purpose that these evaluations can be subject to an external peer of revision. 


\section{Funding}

During the preparation of this article, Alicia Camelo-Guarín received support from the 727 Colciencias Scholarship for National Doctorates in Colombia and the Universidad del Norte. During the preparation of this article, Ana María del Río-González received support from the National Institute of Mental Health (R34MH111362) and the District of Columbia Center for AIDS Research (P30AI117970).

\section{Affiliation}

(a) Department of Social Communication, Universidad del Norte. Km 5, Vía a Puerto Colombia, Bloque D, Piso 2, Of 2-3D. Barranquilla, Colombia.

(b) Student at PhD Program in Social Sciences, Universidad del Norte. Barranquilla, Colombia.

(c) Department of Psychology, The George Washington University. Washington, United States of America.

(d) Department of Psychology, Universidad del Norte. Barranquilla, Colombia.

\section{Authors contributions}

All authors actively participated in all stages of the preparation of the manuscript.

\section{Copyright}

This article is distributed under the terms of the Creative Commons Attribution 4.0 International License, BY type (https://creativecommons.org/licenses/by/4.0/deed.en).

\section{(cc) BY}

\section{References}

1. UNAIDS. UNAIDS DATA 2018 [Internet]. Geneva; 2018 [cited 2018 Nov 30]. Available from: http://www.unaids.org/sites/default/files/media_asset/unaidsdata-2018_en.pdf

2. UNAIDS. Report on the global AIDS epidemic 2013 [Internet]. Geneva; 2013 [cited 2018 Feb 27]. Available from: http://www.unaids.org/sites/default/files/media_asset/ UNAIDS_Global_Report_2013_en_1.pdf

3. Agha $S$. The impact of a mass media campaign on personal risk perception, perceived self-personal risk perception, perceived self-efficacy and other behavioral predictors. AIDS Care. 2003; 15:749-62.

4. UNAIDS. How AIDS changed every things [Internet]. Geneva; 2015 [cited 2017 Mar 26]. Available from: http://www.unaids.org/sites/default/files/media_asset/ MDG6Report_en.pdf

5. Bretón-López J, Buela-Casal G. Análisis de la publicidad preventiva de VIH/SIDA y su impacto en adolescentes en función de variables psicológicas [thesis]. Granada: University of Granada; 2007.

6. Wayling S. The European experience: public education with regards to AIDS prevention. Int J Health Educ. 1988; 7:16-20.

7. Holtgrave D. Public health communication strategies for HIV prevention: past and emerging roles for mass media. AIDS. 1997; 11:183-90. 
8. Rogers EM, Storey JD. Communication campaigns. In: Berger CR, Chafee SH, editors. Handbook of communication science. London: Sage; 1987. p. 817-46.

9. Noar S. A 10-year retrospective of research in health mass media campaigns: where do we go from here? J Health Commun. 2006; 11(1):21-42.

10. Flay BR, Cook TD. Three models for summative evaluation of prevention campaigns with a mass media component. In: Rice RE, Atkin CK, editors. Public communication campaigns. Newbury Park: SAGE Publications; 1989. p. 175-95.

11. Robinson MN, Tansil KA, Elder RW, Soler RE, Labre MP, Mercer SL, et al. Mass media health communication campaigns combined with health related product distribution. A community guide systematic review. Am J Prev Med. 2014; 47(3):360-71.

12. Coffman J. Public communication campaign evaluation: an environmental scan of challenges, criticisms, practice, and opportunities. Cambridge: Harvard Family Research Project; 2002.

13. Noar S, Palmgreen P, Chabot M, Dobransky N, Zimmerman R. A 10-year systematic review of HIV/AIDS mass communication campaigns: have we made progress? J Health Commun. 2009; 14(1):15-42. Doi: http://dx.doi. org/10.1080/10810730802592239.

14. Vidanapathirana J, Abramson MJ, Forbes A, Fairley C. Mass media interventions for promoting HIV testing. Cochrane Database Syst Rev. 2005; 3(3):CD004775.

15. Bertrand J, O’Reilly K, Denison J, Anhang R, Sweat M. Systematic review of the effectiveness of mass communication programs to change HIV/AIDS-related behaviors in developing countries. Health Educ Res. 2006; 21(4):567-97.

16. Huedo T, Boyntonb M, Warrena M, LaCroixa J, Careyc M, Johnsona B. Efficacy of HIV prevention interventions in Latin American and Caribbean Nations, 19952008: a meta-analysis. AIDS Behav. 2010; 14(6):1237-51.

17. LaCroix J, Snyder L, Huedo T, Johnson B. Effectiveness of mass media interventions for HIV prevention, 1986-2013: a meta-analysis. J Acquir Immune Defic Syndr. 2014; 66 Suppl 3:S329-40.

18. French R, Bonell C, Wellings K, Weatherburn P. An exploratory review of HIV prevention mass media campaigns targeting men who have sex with men. BMC Public Health. 2014; 14:616.

19. Friedman A, Kachur R, Noar S, McFarlane M. Health communication and social marketing campaigns for sexually transmitted disease prevention and control: what is the evidence of their effectiveness? Sex Transm Dis. 2016; 43 (2 Suppl 1):83-101.

20. McDaid L, Riddell J, Teal G, Boydell N, Coia N, Flowers P. The effectiveness of social marketing interventions to improve HIV testing among gay, bisexual, and other men who have sex with men: a systematic review. AIDS Behav. 2019; 23(9):2273-303.

21. Sewak A, Singh G. Integrating social marketing into Fijian HIV/Aids prevention programs: lessons from systematic review. Health Commun. 2017; 32(1):32-40.

22. Suárez N. Comunicación en estrategias de mercadeo social del condón masculino para la prevención del VIH/sida en Cuba. Rev Comun Salud. 2014; 4:69-83.

23. Páez D, Mayordomo S, Igartua JJ, Ubillos S, Alonso M, Martínez A. Afectividad, cognición y persuasión: un contraste experimental de las variables mediadoras en la prevención ante el VIH/SIDA. Rev Electronica Motivacion Emocion. 2001; 4(7):1-25.

24. Hassig S. Measuring the effectiveness of targeted interventions. Network. 1991; $12(1): 21-3$. 
25. Anderko L, Uscian M. The effectiveness of a community-level HIV/STD prevention program in a three-country rural area. Fam Commun Health. 2000; 23:46-8.

26. Millar S, Exner TM, Williams SP, Ehrhardt AA. A gender-specific intervention for atrisk women in the USA. AIDS Care. 2000; 12(5):603-12.

27. Bretón-López J, Buela-Casal G. Cuestionario para la evaluación del impacto de campañas publicitarias sobre prevención del VIH/SIDA. Psicothema. 2006; 18(3):556-63.

28. Souza MD, Silva MDD, Carvalho RD. Integrative review: what is it? How to do it? Einstein (São Paulo). 2010; 8(1):102-6.

29. Donovan RJ, Boulter J, Borland R, Jalleh G, Carter O. Continuous tracking of the Australian National Tobacco Campaign: Advertising effects on remembrance, recognition, cognitions, and behavior. Tob Control. 2003; 12 Suppl 2:30-9.

30. Ajzen I, Fishbein M. Understanding attitudes and predicting social behavior. EnglewoodCliffs, NewJersey: Prentice-Hall; 1980.

31. Vernon R, Ojeda G, Murad R. Incorporating AIDS prevention activities into a family planning organization in Colombia. Stud Fam Plann. 1990; 21(6):335-43.

32. Rico B, Bronfman M, Del Rio C. Las campañas contra el sida en México: ¿los sonidos del silencio o puente sobre aguas turbulentas? Salud Publica Mex. 1995; 37(6):643-53.

33. Burgos M. Argentina: social crisis and AIDS prevention campaigns. Int Med J. 1996; 3:35-7.

34. Roso A. Ideology and gender relations: a reception study about AIDS prevention campaigns. Cad Saude Publica. 2000; 16(2):385-97.

35. Chile. Ministerio de Salud. División de prevención y control de enfermedades subsecretaria de salud pública. Evaluaciones campañas de comunicación social años 2003 al 2007. Programa nacional de prevención y control del VIH/SIDA y las ITS. Santiago, CHL; [s.d.].

36. Vera-Gamboa L, Cerón B, Góngora-Bianchi RA. Hombres que tienen sexo con hombres: conocimientos y prácticas sexuales en relación a la epidemia del VIH/SIDA en Mérida, Yucatán, México. Rev Biomédica. 2004; 15(3):157-63.

37. Vera-Gamboa L, Cen-Chablé M, Góngora-Bianchi RA. HIV/Aids: Knowledge attitudes and sexual practices in a group of men who have sex with men in a rural community of Yucatán. Arch Hispanoam Sexol. 2003; 9:191-204.

38. Flores F, De Alba M. El SIDA y los jóvenes: un estudio de representaciones sociales. Salud Mental. 2006; 29(3):51-9.

39. Nielsen R, Luengo M, Mello M, Paz J, Pantin C, Erkkola T. Social media monitoring of discrimination and HIV testing in Brazil, 2014-2015. AIDS Behav. 2017; 21 Suppl 1:114-20.

40. Porto MP. The fight against AIDS among adolescent girls: the impact of the 2003 Carnival campaign by the Brazilian Ministry of Health. Cad Saude Publica. 2005; 21(4):1234-43.

41. Ahumada M, Ruiz M, Parra V. Observatorio de Políticas Públicas en VIH/SIDA desde la Perspectiva de Derechos Humanos: "Campaña de comunicación social de prevención del VIH/SIDA”. Chile: Savia Foundation; 2012.

42. Reynaga C. Evaluación del impacto de una campaña de prevención del VIH e ITS en adolescentes del Perú [tesis]. Barcelona: Universidad Autónoma de Barcelona; 2015. 
Foi feita uma revisão integrativa da literatura dos últimos trinta anos sobre avaliações de estratégias de prevenção ao HIV implementadas nos meios de comunicação de massa na América Latina. Foram identificados 246 documentos, dos quais 12 atenderam aos criterios de seleção e 15 avaliações de campanhas foram identificadas. Os resultados indicam que a mensagem mais usada foi promover o uso de preservativos. A maioria das avaliaçóes focou em lembrar a mensagem das campanhas. Apenas três apresentam resultados de avaliaçóes do conhecimento e outros dois sobre a atitude em relação ao uso de preservativos. Cerca de nove relataram mudanças comportamentais. Concluindo, existem poucos artigos com resultados de avaliação desse tipo de campanhas. A avaliação comportamental é cada vez mais levada em consideração. Desenhos de avaliação pré-experimental com uma única medida pós-teste e sem um grupo controle são utilizados.

Palavras-chave: Campanhas. Prevenção ao HIV/Aids. Mercados sociais. Comunicação em saúde. América Latina.

Se realizó una revisión integradora de la literatura de los últimos treinta años sobre las evaluaciones de las estrategias de prevención del VIH implementadas en los medios de comunicación masiva en América Latina. Se identificaron 246 documentos, de los cuales 12 cumplieron los criterios de selección, y se identificaron 15 evaluaciones de campañas. Los resultados indican que el mensaje más utilizado era promover el uso del condón. La mayoría de las evaluaciones se centraban en recordar el mensaje de las campañas. Solo tres arrojan resultados de evaluaciones de conocimientos y otras dos sobre la actitud frente al uso del condón. Acerca de nueve cambios de comportamiento. En conclusión, existen pocos artículos con resultados de evaluación de este tipo de campañas. Se utilizan diseños de evaluación pre-experimentales con una única medida pos-test y sin grupo control.

Palabras clave: Campañas. Prevención de VIH/SIDA. Mercadeo social. Comunicación en salud. América Latina. 